\title{
RESEARCH ON THE MOTIVATION FOR CHOOSING THE MILITARY CAREER
}

\author{
Grigor GRIGOROV, Svilen SPIRDONOV \\ "Vasil Levski" National Military University, Veliko Tarnovo, Bulgaria \\ gbgrigorov@nvu.bg, saspirdonov@nvu.bg
}

\begin{abstract}
The following article examines the structure of the motivation to choose the military career as well as the satisfaction from it. It analyses the main factors influencing on the choice of this profession as well as the interrelationships between them. The article sets out the specific reasons for a career in the Army and the results of the survey would contribute to the improvement of the attractiveness of the military career and attracting motivated military staff.
\end{abstract}

Keywords: motivation, military career, choice, military staff

\section{Introduction}

"Have you ever thought about a career in the Army? It is more than just a well-paid state job, it is about the honour to serve. It will also teach you how to be more disciplined, to improve your qualification. Moreover you will be a part of something bigger and more important, you will serve our country, just like me and your grandfather." [6].

This is an example of a conversation between many fathers and their grown-up children in searching of the "right way" on the path of life. However, what is the reason for choosing that career - "defender of the fatherland", may say only those who have chosen to service in the Army.

In today's complex and changing security environment, we seek and apply purposefully methods, techniques and means in order to hire skilled, highmotivated and loyal military staff, who is able to realize the organizational goals set. Solving this problem is not very easy because in today's globalized world there are a lot of opportunities for the young people. Therefore it becomes increasingly difficult to attract them to this hard profession - the military service. It is known that the human resources are the most valuable in one organization and it is often said that the organization is as good as its staff. We are faced with the necessity of looking for the reasons for choosing this profession and developing new models for attracting and retaining motivated staff to perform their duties.

The term "motivation" comes from Latin and means "move", "stir" [4, p. 167]. In the dictionary of foreign words in Bulgarian, the translation of "motivation" is "a set of motives that determine a certain activity or action", but "motive" should be understood as "incentive, occasion, reason for action" [1, p. 424]. Therefore, the motivation is the reason, the incentive, and the force that leads people to act in a certain way in order to achieve their goals. The motive, on its part, is a conscious motive, determinant action to satisfy some human needs.

The analysis of the existing literature shows that motivation has a complex structure and is inherent only to the individual or the person, as a characterized by a high degree of consciousness [3, p. 172]. For these reasons, many authors, such as Frederick 
Taylor, Elton Mayo, William Ouchi, Abraham Maslow, Frederick Herzberg, Victor Vroom, David McClelland, Burrhus Skinner, Étienne-Jules Marey and others, have considered it. [2, p. 21-37]. In their works, they developed various motivational theories, and then L. Mullins structured them into two main groups. In the first group are included the "contend theories of motivation" as defined by him, and in the second - "process theories of motivation" [5].

The first group includes Maslow's Hierarchy of Needs Theory, Herzberg's Two-Factor Theory of Motivation, McClelland's Human Motivation Theory, Alderfer's ERG theory and Murray's Theory of Psychogenic Needs. All the authors in that group examine the motivation for work in terms of its content characteristics, assuming that it can be linked to the mechanism of the action of human needs. The main question is "What stimulates a specific behaviour?" For example, Herzberg accepts and develops Maslow's theory for the hierarchy of human needs. However, Maslow divides the factors that influence on the human's behaviour in two main groups - external (hygiene factors) and internal (motivators). The external factors correspond to the lower levels of Maslow's theory, and their lack affects directly the choice of profession, because of the fact that they are visible for the environment surrounding the organization. The internal factors are connected with the specific workplace and increase the satisfaction of the job.

The second group of process theories of motivation includes Vroom's, Porter's and Lawler's Expectancy Motivation Theories, Adam's Theory of Justice, Heider's and Kally's Theory of Attribution and Locke's Goal-setting Theory. These theories are connected with the authors' understanding of the essence of the motivation as a process. Their theories put an accent on the psychological processes participating in the formation of the motivation. They clarify why people choose a specific behaviour to meet specific needs. It is necessary to be mentioned, that the transition through the stages of the motivation process leads to the satisfaction of one need, but when a new need arises, the process resumes. Therefore, the motivation process is cyclical as people have complex of needs that are constantly enriched and renewed.

The aim of this study is to determine the motivational structure for choosing a military career in the Republic of Bulgaria, revealing the hierarchy of the motives for choosing it and establishing the relationship between them.

The working hypothesis in the study is: dominating in the motivational structure when choosing the military profession are the factors related to the external motivation (or Herzberg's hygiene factors), because they are visible to the others, e.g. payment, working conditions, relationships, and social benefits, compared to the internal factors (or Herzberg's (motivators), which relate to the specific of the particular work, autonomy, the achievements and the recognition.

\section{Methodology for conducting the study}

The study of the motivation for choosing the military career is based on a methodology, specifically designed for the needs of this study, based on a data collection through an online survey. The subject of the survey are three main target groups (categories) military staff from the armed forces of the Republic of Bulgaria, as follows:

- soldiers and sergeants;

- officers;

- cadets from Vasil Levski National Military University.

The scope of the survey is in number of canvass by category:

- soldiers and sergeants - eighty three (83) people;

- officers - fifty three (53) people;

- cadets from Vasil Levski National Military University - two hundred and 
twelve (212) people.

In order to achieve the goals of the empirical research is developed a questionnaire, identical for all of the categories. It includes two main parts: first passport part, second - question part, structured in groups to reflect the opinion of the people questioned.

The passport part includes general information about the interviewees.

The second part includes twenty questions and the answer is in the form of a Likert scale.

The scale contains five point answer options: 1 - very unsatisfied; 2 - unsatisfied 3 - neutral; 4 - satisfied; 5 - very satisfied.

\section{Analysis of the results}

The analysis of the results from the conducted survey is prepared on separated or group questions from the questionnaire, and examines the opinion of all of the inquired categories.

Question №1 is:

"To what extent do you think the choice for the military career is personally yours?"

The results of question 1 are shown in Fig. 1 . The analysis shows that the majority over $70 \%$ estimate in a satisfied and very satisfied degree that the choice of the military career is theirs.

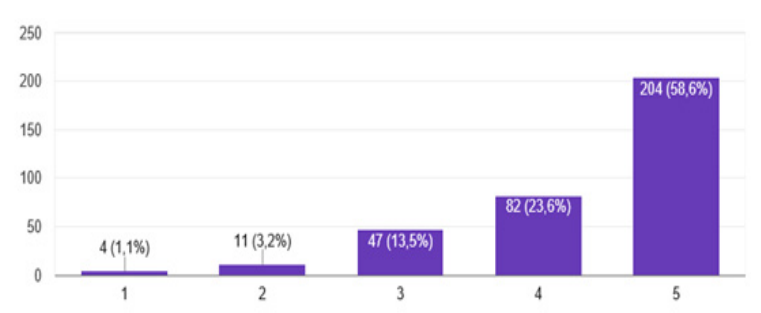

Figure 1: Answer to question 1.

Questions № 4, № 5, № 6 and № 7 of the questionnaire refer to the prestige of the military career, the respondent's opinion of what is its current state and how has it changed during the time.

The answers show, that the majority of the respondents consider the military career as prestigious in the neutral and satisfied degree. The opinion of over $60 \%$ of the respondents is that there are not made enough steps in order to raise the prestige of military career. Almost all of the respondents are agreed on the view that compared to the past, nowadays the prestige of the military career is decreasing.

Question №8 of the questionnaire is:

"To what extent do you think the following factors are important for choosing the military career?"

This question is subdivided into twenty items, containing various factors influencing on the choice for the military career. In this way, the respondents have the opportunity to indicate what they think about the degree of importance of each of the indicated factors.

Part of the results of question 8 are shown in Fig. 2. The results show that the main factors for choosing the military career are the opportunity for an early retirement, the salary, certainty and predictability at the workplace, opportunities for improvement and career development, appropriate (regulated) working time, obtaining free education for cadets and opportunities for work with weapons and military equipment. Patriotic motives are also extremely important, and this is noticeable from the unanimous opinion of the respondents that their choice allows them to serve their homeland. It is also important the opportunity for teamwork and participation in international operations (missions), especially for soldiers. The social status of the military profession and the benefits from it are also indicated as very important for the majority of respondents.

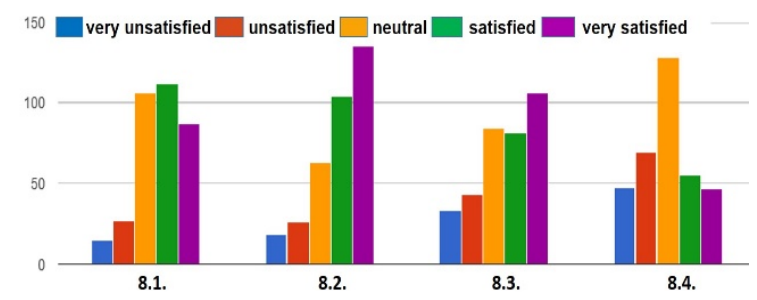

Figure 2: Answer to question 8.

As less important factors for choosing the military career the respondents point the 
need for a frequent change of the residence, location of working place, restrictions on personal rights and freedoms, and the freedom to make their own decisions at the workplace.

The analysis of these questions shows that the motivation to choose the military career is a complex composition consisted of many different interrelated factors. The predominant part of them are the external (hygienic) factors of Herzberg, which are very important in the choice of the military career, and in addition, they are in a combination with the patriotic motives of the person. However, it is not enough only to change one of them in order to find a solution of the problem with the reduced number of people, wishing to serve in the Army. All these factors need to be considered together, in a unified system and changed in a balanced and interrelated way.

Question №10 of the questionnaire is:

"Do you think that the frequent statutory changes affect negatively the choice to serve in the Army?"

The results of the question № 10 show, that the respondents are united in their opinion that the frequent statutory changes affect negatively the choice of the military career as well as those who have chosen it.

Questions №11 and №12 concern the relationship between the choice for the military career and the resource provision, the technical condition of the armament, the military equipment and the infrastructure. The questions are:

Question №11 - “To what extent do you think that the interest for the military career is reduced because of the systematic and insufficient resources provision?"

Question №12 - “To what extent do you think that the interest for the military career has declined because of the old military equipment and infrastructure and the slowdown in the modernization?"

The results of question №11 are shown in Fig. 3. The results show that all of the respondents are aware of the systematic and insufficient provision of resources and the delay of the modernization of the outdated equipment, armaments and infrastructure have an adverse effect on the interest for the military career. On the one hand, the respondents are willing to work with weapons and military equipment. On the other hand, they are faced with the problems in their maintenance and exploitation, so their desire quickly disappears.

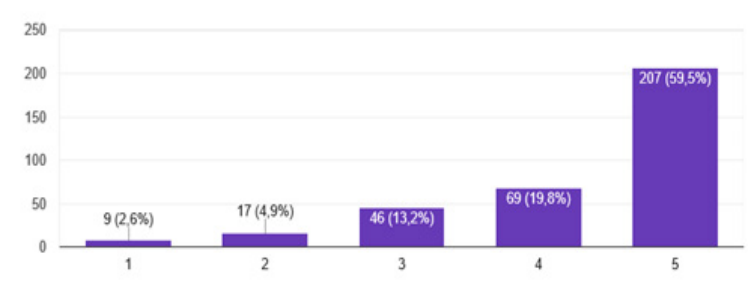

Figure 3: Answer to question 11.

Question №13 of the questionnaire is:

"To what extent do you think that if the relationship between the society and the army improves, there will be an increase of the interest for the military career?"

The results of question №13 show that about $75 \%$ of respondents are unanimous that the interest for the military profession is in direct proportion to the relationship between the society and the army. This shows that there is a need for constantly work towards improving this relationship in order to increase the interest for the military career.

Questions №14, №15, №16 and №17 of the questionnaire are related to the civilmilitary relations and the popularity of the military career in the society. The analysis of the results shows that a large number of respondents (over $40 \%$ ) believe that the civil-military relations are at an average level. Besides, more than $70 \%$ of respondents believe that the public is not aware of the current army activities and the possibilities for serving in the Army. Almost all of the respondents are of the opinion that this career must be promoted by the media. This shows that there are not enough efforts for strengthening the armysociety relationship, which is also one of 
the main problems responsible for the low interest for the military career and the opportunities for serving in the Army.

Questions №18, №19 and №20 of the questionnaire are related to the satisfaction for choosing the military career.

The results show that for the majority of respondents $(56 \%)$ the satisfaction from the choice for the military career is relatively high. The respondent's opinion is that their expectations from choosing a career are justified on an average degree. About 45\% say they would repeat their choice but almost $30 \%$ hesitate. This shows that despite the difficulties they encounter almost every day, they would once again devote their lives to serve in the army.

From the study of the motivation to choose the military career and analysis of the results, the following conclusions can be reached:

More than $70 \%$ of the respondents declare that the choice for the military career is personally theirs, but only half of them had been aware of the nature of their future activities before they went in the army. Furthermore, the majority of the respondents consider that the military career is prestigious in the society, but over $60 \%$ of them believe that there are not made enough steps in order to raise the prestige of military career, and today it decreases. The analysis of the results from the study of the motivation for the choice to serve in the Army highlights the external (hygienic) factors of Herzberg before the internal (motivators), which proves the hypothesis of the study that the external factors are decisive in the initial choice of a career, because they are eminent before starting the job. The most important of these are the early retirement, the salary, security and predictability at the workplace, opportunities for improvement and career development, appropriate (regulated) working time, obtaining free education for cadets and opportunities for work with weapons and military equipment

The outlined key factors are important, but it should be noted how some of them are changing. In the last five years from 2013 to 2018 , the people working in the Army were given a pay rise only once - in the beginning of 2018. The average amount of it is between 8 and $10 \%$ of the salary. Compared to the rise of the minimum salary with more than $65 \%$ (from BGN 310 to BGN 510) for the same time and including the inflation, it comes out that the pay rise is even with an opposite sign.

The next major factor is that the early retirement is no longer attractive, because of the latest retirement changes from 2016 year. The retirement age for 2018 is 53 years and 2 months, and it is going to be increased each year with 2 months until reaching 55 years. In addition, it is required at least 27 years of professional experience in the army.

All of the surveyed categories are consolidated around the opinion that the frequent statutory changes affect negatively the choice of the military career as well as those who have chosen it. It is also necessary to point out that the systematic and insufficient funding and resource provision and the delay of the modernization in the army are not only an obstacle for the vacancies to be filled, but also demotivate those who have chosen to serve in the army. The analysis of the results of the civil-military relations shows that they are at an average level and the respondents agree that the interest for the military career is in a direct relation with the relationship society - army. The majority of respondents believe that the public is not aware of the current army activities and the possibilities for serving in the army. Almost all of the respondents are of the opinion that it is necessary to promote this career, especially through the media.

On the positive side, the opinion of almost all respondents is that the military career brings them satisfaction above the average, and that their expectations for choosing a military career are justified, $45 \%$ would 
repeat their choice. These results indicate that there is still motivated staff in the army and despite the difficulties that they are faced to, they are able to perform their duties. However, this should not be a relief because the tendency for attracting motivated staff is worrying, and despite the efforts of the government, the vacancies in the army are increasing rather than decreasing. For this reason, it is necessary to develop a comprehensive resourceassured strategy, including all deduced basic factors for attracting and retaining the most important resource in the army - the human resources.

\section{Conclusions}

The analysis of the results from the civilmilitary relations shows that the interest for the military career is in a direct relation to the relationship between society and army, if the relationship is stronger, the interest will be greater. This leads to the need for strengthening this link and popularizing the military career in the society, especially through the media.

The summarized and analysed results of the conducted survey show that the motivation for choosing the military career is a complex system of interrelated factors, the predominant part of which are the external (hygienic) factors of Herzberg. Therefore, all of these factors need to be considered together and changed in a balanced way to solve the problem with the reduced number of candidates for serving in the army.

\section{References}

[1] Буров, С., Пехливанова, П. Речник на чуждите думи в български, Велико Търново, Елпис, 1995, с. 424.// Burov, S., Pehlivanova, P. Rechnik na chuzhdite dumi v balgarski, Veliko Tarnovo, Elpis, 1995, p. 424.

[2] Пенчева, И. Организационно поведение, Велико Търново, Абагар, 2007, с. 2137.//Pencheva, I. Organizatsionno povedenie, Veliko Tarnovo, Abagar, 2007, p. 21-37.

[3] Иванов, И. Организационна психология, Велико Търново, Фабер, 2005, с. 172.// Ivanov, I. Organizatsionna psihologia, Veliko Tarnovo, Faber, 2005, p. 172.

[4] Пенчев, П., Пенчева, И. Основи на управлнието, Абагар, 2002, с. 167.// Penchev, P., Pencheva, I. Osnovi na upravlnieto, Abagar, 2002, p. 167.

[5] Mullins, L., Management and Organisational Behaviour, London, 2013.

[6] http://landforce.mod.bg/Profesiya-voenen/10:543.html - (last visited 08.01.2018 $16,25)$. 